Mukendi Baloji Emmanuel, Doctor of Philosophy (Ph.d), Chief Executive Officer ${ }^{1}$

E-mail: mukendie@yahoo.com

P. Baranov, Doctor of Geological Sciences, Professor, Forensic expert ${ }^{2}$

E-mail: pn2dsbaranov@gmail.com

${ }^{1}$ GBJConsulting LTD. and Mikas SARL

Canada DR Congo

${ }^{2}$ Dnipropetrovsk SRECC MIA of Ukraine

1 Constructional dead-end street, Dnipro, 49033, Ukraine

\title{
Prospects for scattered diamond occurrences in the Kasai province of the Democratic Republic of the Congo
}

\section{(Recommended by M. Ruzinoy, Doctor of Geological Sciences)}

The article discusses the results of the expedition, which was organized by MIKAS sarl, a JV of the DR Congo state company MIBA and the Canadian company GBJ CONSULTUNG LTD. The purpose of the expedition is to assess the prospects of the alluvialdeluvial deposits of the Kasai River for diamonds and other minerals. Also considered and tested technological schemes for the extraction of diamonds from the rock mass in specific areas.

Key words: diamonds, assessment of the prospects of deposits, alluvial-deluvial deposits, minerals, technological schemes.

\section{Relevance}

In the province of Kasai, diamonds are mined by the local population by hand using shovels, a tray and sieves. At the same time, completely neglecting safety precautions. To develop a project for the extraction of diamonds from alluvial deposits by a semi-industrial method and other minerals, additional information on geology, processing technology in specific natural conditions was required, which determined the goals and objectives of this expedition.

\section{Links with previous research}

After a diamond was found in Central Africa in 1907, industrial mining of precious stones from placers was revived. Geological exploration of the territory by Belgian companies was actively carried out. After the proclamation of independence, the DR Congo in the 60s of the last century interrupted the industrial mining of alluvial diamonds in the province of West Kasai , and as a result, the systematic geological exploration of the region ceased. Therefore, there are practically no detailed works on geological study. At the same time, there are a number of publications on a regional scale, where issues of a genetic nature, the possibility of sources of removal of diamonds from the Angolan crystalline massif are discussed.

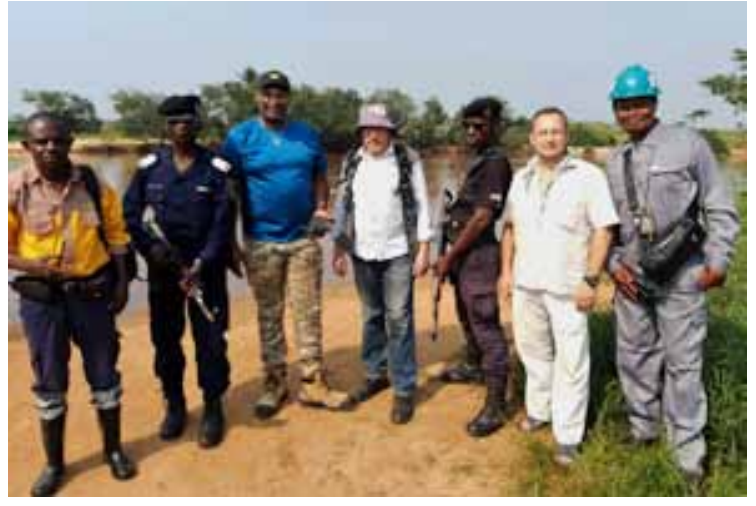

Geologists of Canada, DR Congo, Ukraine

\section{Formulation of the problem}

At present, the companies have received permission for geological exploration of 17 permits within the alluvial-deluvial deposits of the Kasai River with the subsequent receipt of a license for the extraction of diamonds and other minerals. To assess the prospects of the sites, an international expedition was created which included representatives of the Congolese company MIKAS, the Canadian company GBJCONSULTUNG LTD and specialists from Ukraine. 


\section{Presentation of the main results}

Moving from the capital of DR Congo (Kinshasa) to the diamond capital (Tshikapa) of Kasai province took 2 days. Although the distance is $930 \mathrm{~km}$, taking into account African roads and unforeseen situations, it took so much time to get there.

On the first day of his stay in the mining village of Chikapa, a meeting was held with the vice-governor of Kasai province GASTON NKOLE TSHIMUANGA. Much has been said about attracting investment to this region and about our role in these projects. The main problem of the region is unemployment and lack of roads.

Support was provided at the highest level: the meeting was shown on local television with an appeal to the local population for assistance in the movement of our expedition; reliable security was allocated (4 police officers in full gear).

Everywhere we were greeted by friendly faces and always asked for money. It was strictly forbidden to give money to us, as this, as a rule, leads to fights among the population.

Many people, especially children, saw white people for the first time. Therefore, from morning until late evening, crowds of local residents were around our camp.

Diamond mining in the province is carried out in two ways: on land and from the bottom of the Kasai River.

Floodplain and above-floodplain terraces are underlain by gravel, which contains diamonds (though not always). The extraction of pebbles is carried out with primitive tools: shovels, picks, machetes. To get to the productive layer, you have to dig pits up to $5 \mathrm{~m}$.

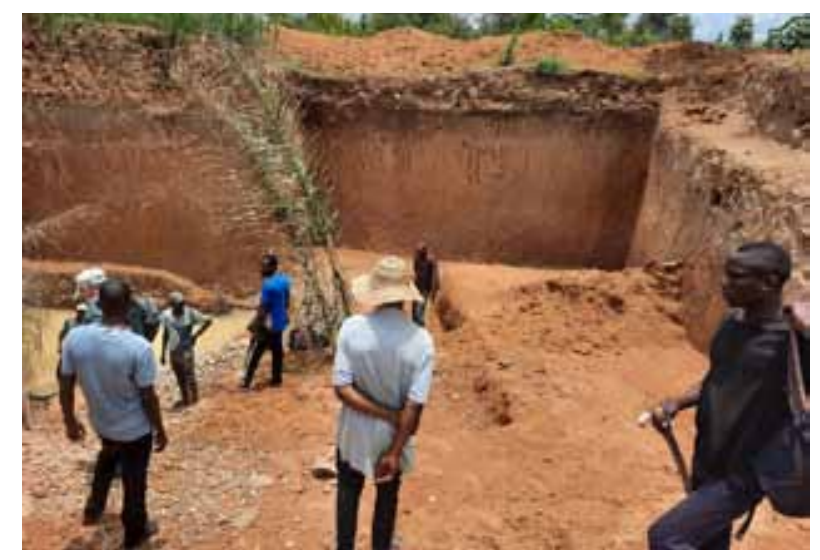

Extraction of diamond-bearing pebbles

Then the gravel in bags is taken to the river and the extracted material is washed with the help of special trays. It is quite difficult to see and distinguish diamonds among the many crystals of quartz and other minerals without the appropriate experience and skill.

At the same time, diamond, due to its high hardness, retains its octahedral natural shape, which allows an experienced rinser to isolate it from the bulk of the minerals.

After the uncontrolled mining of diamonds, as a rule, socalled. "Lunar landscapes". Nobody is engaged in land reclamation. Roads too. Where the funds from the sale of precious stones go, one can only guess.

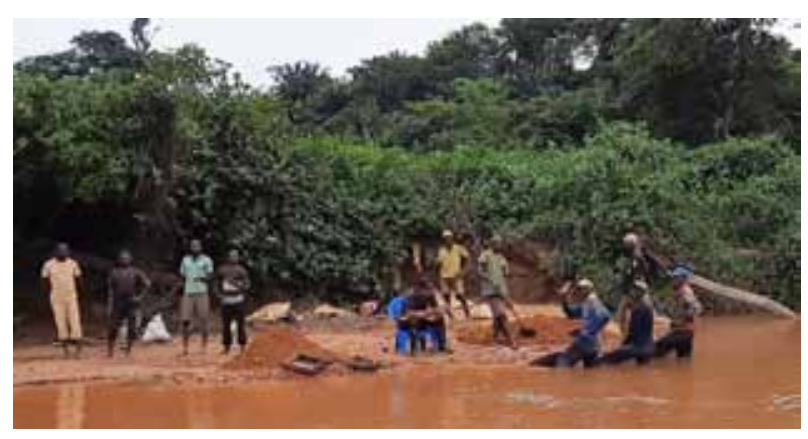

Pebble washing is carried out under the supervision of a trustee (seated in a blue chair)

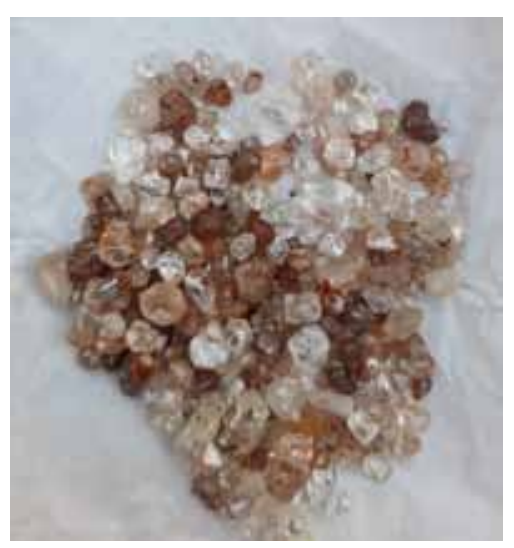

Diamonds of various shapes and colors. The total weight of stones over 60 carats, the largest (top left) octahedral shape 3.71 carats

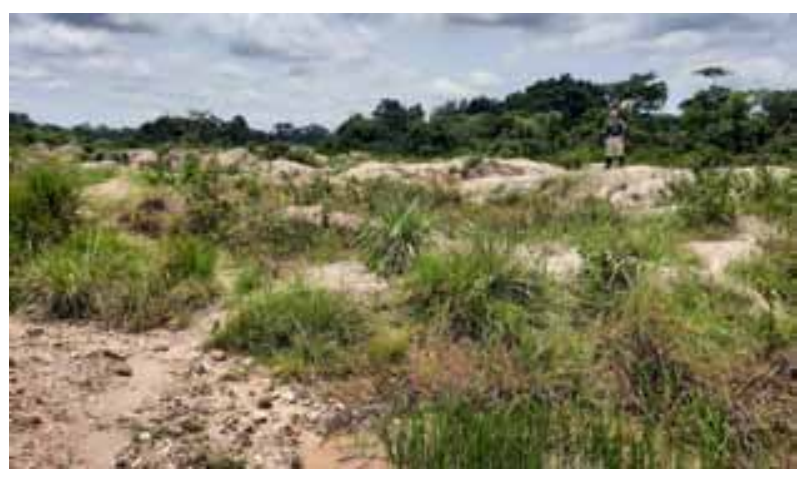

"Lunar landscapes" are observed after areal mining

The second method of diamond mining is collecting alluvial deposits from the bottom of the Kasai River. The extraction is carried out with the help of divers-divers, equipped with primitive equipment: a wetsuit and a hose through which air is supplied from a conventional compressor. A diver from the bottom of the river in pitch darkness (the water is muddy with a reddish-brown tint) to the touch rakes gravels into bags and lifts them into the boat. They often work until late in the evening and even at night. The depth of the river in this section is $6-8 \mathrm{~m}$. The material raised from the bottom of the river is washed on the bank. 


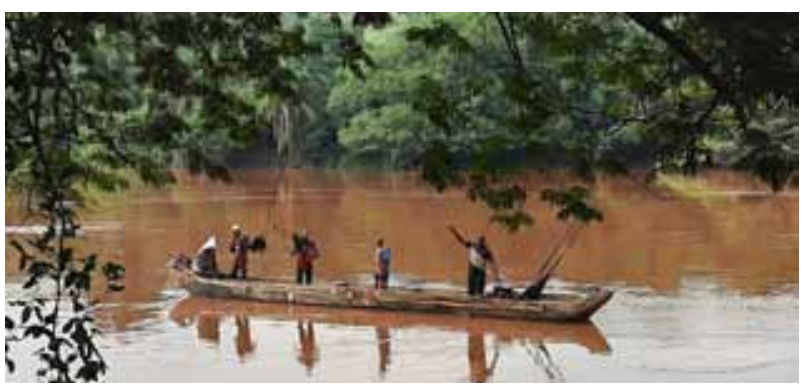

Wooden boat equipped with a compressor to supply air to the diver. In places where crocodiles are found, this type of mining is not practiced

We have laid about 10 mine works in various areas in modern alluvial deposits (floodplain), above floodplain terraces. The benefit of the workforce in these places is abundant.

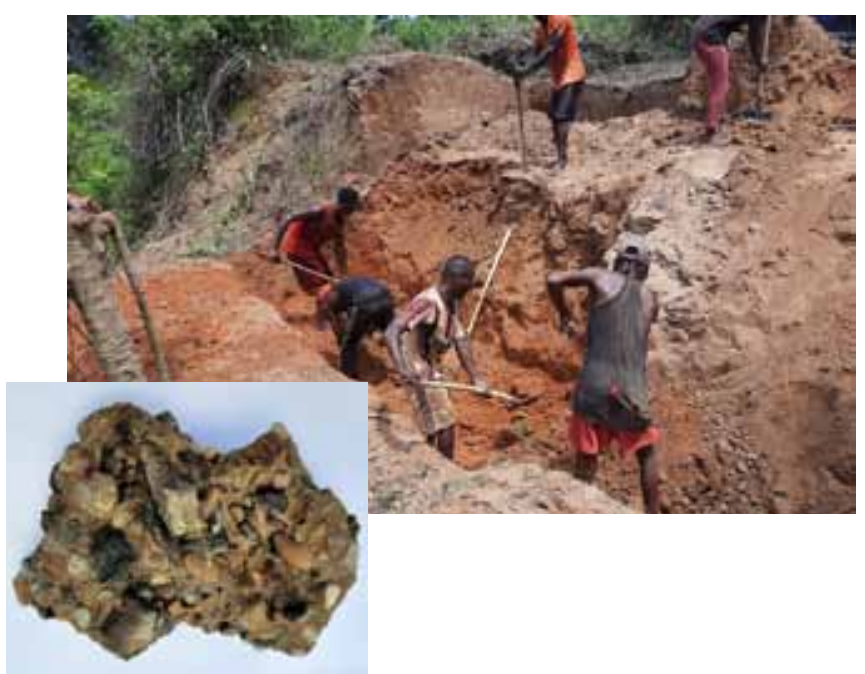

Uncovering works to diamond-bearing pebble (on the left)

In addition, an order was made for an alluvial gravel sampling from the bottom of the Kasai River, weighing $500 \mathrm{~kg}$. The order is completed quickly and delivered in bags.

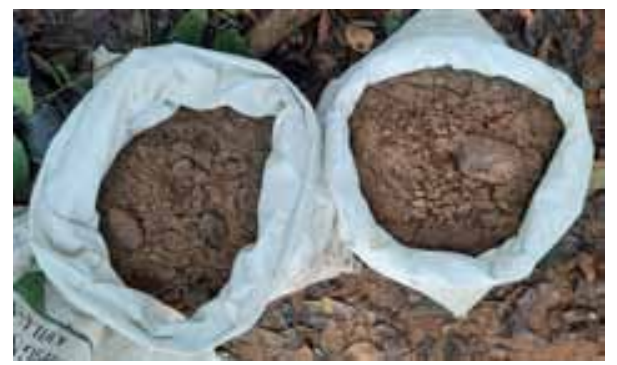

Pebbles extracted from the bottom of the Kasai River

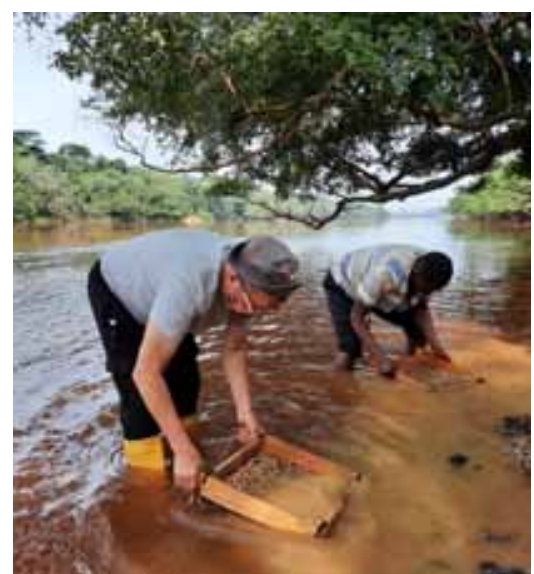

Washing of alluvial sediments extracted from the bottom of the Kasai River

At the end of the work, methods were proposed for mining diamonds in alluvial deposits of floodplains and above-floodplain terraces, as well as in alluvial deposits at the bottom of the Kasai River. The corresponding proposals were submitted for consideration to investors and the Congolese company MIKAS sarl; a JV of state owned company of DR Congo "MIBA" and GBJCONSULTING LTD, an Ontario registered corporation.

The second proposal, which turned out to be new and unexpected for all participants in this project, including for us, is agate, jasper, quartz, in the form of well-rounded pebbles on the day's surface. In fact, it is one of the components of the diamondcontaining layer. Many of the colored stones hid the stone's true beauty under black and brown-red shirts.
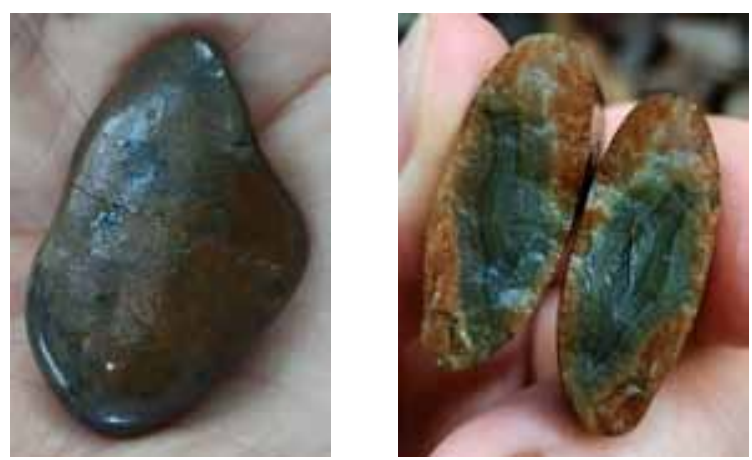

On the left is a dark gray pebble, after splitting it (on the right) it turns out that it is agate

After a little processing, the true beauty of the stone is revealed.

Agates are tonsils with pronounced zoning. Color from light gray to dark brown. According to the mineral composition, they are subdivided into chalcedony-quartz, chalcedony, quartzchalcedony. 


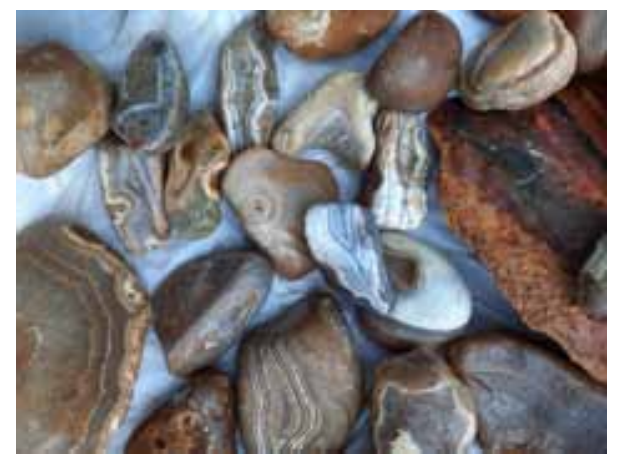

Agates, jaspers, quartz, from floodplain alluvial deposits

Jasper - yellow, red-brown, red. Brocade jasper is sometimes found.
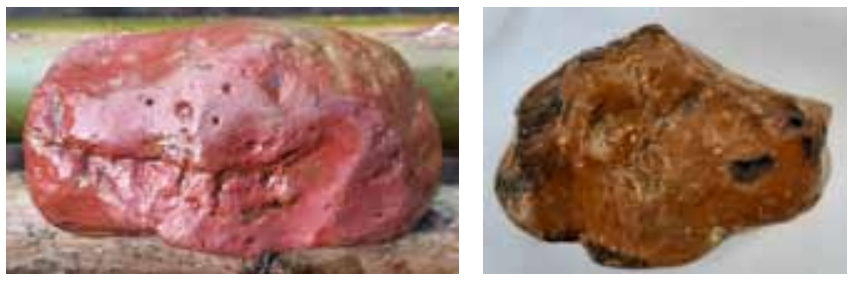

Red and yellow (opal) jasper
For understanding and clarity when collecting colored stones, a reference collection of stones has been compiled. It will serve as a visual aid for local diggers, whose knowledge is limited to one mineral - diamond.

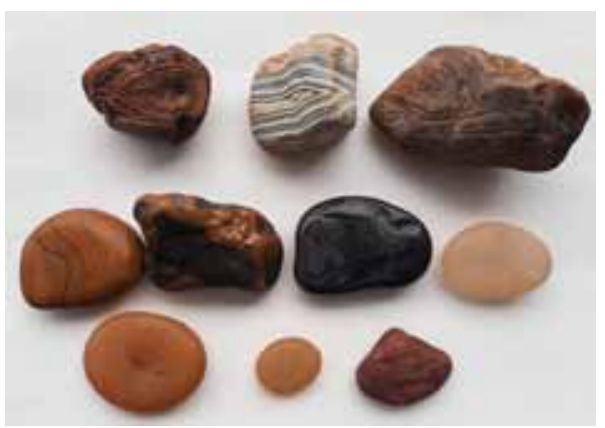

Reference collection of colored stones (agate, jasper, quartz).

According to preliminary estimates, the reserves of this gem in only one site with an area of $2 \mathrm{~km} 2$ are over 3 tons. This is what is now on the surface and ready to be collected. Direct profits are comparable to, and sometimes exceed, the diamond business.

\section{References}

1. Shmakov II, Muniswamy M. Geological environment and evolution of alluvial diamond placers of Kasai Occidental province, DRC // Abstracts of IGSP-514 Fluvial and marine processes of Cenozoic and formation of placers, Thrivananthapuram, India, 2007, pp. 60-63.

2. Shmakov I.I. Geological evolution of diamondiferous marine placers on the coast of South-West Africa // News of higher educational institutions. Geology and exploration. 2008, 3, p. 43-48.

\section{УДК 553.55}

Мукенди Балоджи Еммануель, доктор філософських наук, виконавчий директор ${ }^{1}$ Email: mukendie@yahoo.com

П.М. Баранов, доктор геологічних наук, професор, судовий експерт ${ }^{2}$ E-mail: pn2dsbaranov@gmail.com ${ }^{1}$ GBJ Consulting and Mikas SARL, Канада, ДР Конго

${ }^{2}$ Дніпропетровський НДЕКЦ МВС України, тупик Будівельний, Дніпро, 49033, Україна

Перспективність проявів розсипних алмазів провінції Касаї Демократичної Республіки Конго

У статті розглянуто результати експедиції, яка була організована Державною компанією ДР Конго МІBA і канадською фрірмою GBJ CONSULTUNG LTD. Мета експедиції - оцінка перспективності алювіально-делювіальних відкладень річки Касаї на алмази та інші корисні копалини. Також розглянуті і апробовані технологічні схеми з вилучення алмазів з гірської маси на конкретних ділянках.

Ключові слова: алмази, оцінка перспективності родовищ, алювіально-делювіальні відкладення, корисні копалини, технологічні схеми.

\section{УДК 553.55}

Мукенди Балоджи Эммануэль, доктор философрских наук, исполнительный директор 1 Email: mukendie@yahoo.com

П.Н. Баранов, доктор геологических наук, професссор, судебный эксперт ${ }^{2}$ E-mail: pn2dsbaranov@gmail.com ${ }^{1}$ GBJ Consulting and Mikas SARL, Канада, ДР Конго ${ }^{2}$ Днепропетровский НИЭКЦ МВД Украины, тупик Строительный, 1, Днипро, 49033, Украина

Перспективность проявлений россыпных алмазов провинции Касаи Демократической Республики Конго

В статье рассматриваются результаты экспедиции, которая была организована государственной компанией ДР Конго МІВА и канадской фирмой GBJ CONSULTUNG LTD. Цель экспедиции оценка перспективности аллювиально-делювиальных отложений реки Касаи на алмазы и другие полезные ископаемые. Также рассмотрены и апробированы технологические схемы по извлечению алмазов из горной массы на конкретных участках.

Ключевые слова: алмазы, оценка перспективности месторождений, аллювиально-делювиальные отложения, полезные ископаемые, технологические схемы. 